\title{
A Novel Mutation in the Vasopressin V2 Receptor Gene in a Woman with Congenital Nephrogenic Diabetes Insipidus
}

\author{
Kei Sato, Hiroshi Fukuno, Tetsuzo Taniguchi, Seizo Sawada, Takafumi Fuku** and Moritoshi Kinoshita* \\ A 56-year-old Japanese woman with congenital nephrogenic diabetes insipidus (CNDI) is \\ reported. She was diagnosed with CNDI accompanied by advanced gastric cancer. After total \\ gastrectomy, approximately $500 \mathrm{ml}$ fluid per hour was necessary to prevent dehydration. Urinary \\ volume was decreased by administration of hydrochlorothiazide. We detected a novel mutation in \\ the vasopressin V2 receptor gene of her chromosomal DNA. A substitution from $G$ to A was found \\ at the 631 nucleotide position, altering codon 12 from glycine (GGG) to glutamic acid (GㅁG) in \\ the first extracellular domain. This missense mutation appeared to be the cause of her resistance \\ to arginine vasopressin.
}

(Internal Medicine 38: 808-812, 1999)

Key words: polyuria, vasopressin receptor, missense mutation

\section{Introduction}

Congenital nephrogenic diabetes insipidus (CNDI) is usually an X-linked recessive disease, characterized by renal resistance to the anti-diuretic effect of arginine vasopressin (AVP). AVP binds to specific receptors on renal collecting tubule cells, and a signal is transmitted by interaction with membrane-associated proteins, leading to the production of cyclic adenosine monophosphate (cAMP). Elevation of the intracellular cAMP level increases water permeability via expression of water channels on cell membranes through the activation of protein kinase-A (1). Thus, any defect in these processes might be a cause of CNDI. Human vasopressin V2 receptor gene was cloned in $1992(2,3)$, and distinct mutations in this receptor gene have since been found in CNDI families (4-12).

We describe here a novel mutation identified in a Japanese female with this disorder, a missense mutation from Gly to Glu (G $\underline{G G}$ to $\mathrm{G} \underline{\mathrm{A} G}$ ) at the 12th codon in the first extracellular domain of the vasopressin $\mathrm{V} 2$ receptor gene.

For editorial comment, see also p 755.

\section{Case Report}

A 56-year-old Japanese woman was admitted to our hospital because of palpitation and vertigo. A diagnosis of severe anemia was made. To elucidate the cause of the anemia, gastro- endoscopic examination was performed, and revealed advanced gastric cancer at the greater curvature. Physical examination revealed a normally grown and slightly thin woman. Her height was $153.5 \mathrm{~cm}$, weight $45.0 \mathrm{~kg}$, temperature $36.5^{\circ} \mathrm{C}$, pulse 84 beats/min and regular, and blood pressure $114 / 64 \mathrm{mmHg}$. The lung, heart, abdomen, and extremities were normal. The laboratory data on admission are presented in Table 1. Urinary examination was normal, but hemoglobin level and number of erythrocytes were very low, indicating severe hypochromic anemia. The serum sodium was $150 \mathrm{mEq} / l$, potassium $4.0 \mathrm{mEq} / l$, chloride $114 \mathrm{mEq} / l$, calcium $8.8 \mathrm{mg} / \mathrm{dl}$, and phosphorus 3.5 $\mathrm{mg} / \mathrm{dl}$. Blood urea nitrogen concentration was $6 \mathrm{mg} / \mathrm{dl}$, and creatinine $0.5 \mathrm{mg} / \mathrm{dl}$.

To examine for metastasis of gastric cancer, we examined the abdomen by using computed tomography, which revealed marked bilateral hydronephrosis. We determined her daily urine volume to be $13,200 \mathrm{ml} /$ day with a specific gravity of 1.004 . Since childhood she had drunk approximately 10 liters or more of water per day due to thirst. We therefore suspected diabetes insipidus.

A water deprivation test was performed (Fig. 1). After 5 hours of water deprivation, urinary osmolality was only 44 $\mathrm{mOsm} / l$, while the plasma osmolality rose from 274 to 305 $\mathrm{mOsm} / \mathrm{l}$, and the patient's weight decreased by $3.0 \mathrm{~kg}$. It was $6.7 \%$ of body weight which was measured just before the water deprivation test. These findings indicated diabetes insipidus. Nasal administration of 1-desamino-8-d-arginine vasopressin (DDAVP) was started with an initial daily dose of 10

From the Anan Central Medical Association Hospital and *the Gene-Diagnostic Center, Otsuka Assay Laboratories, Otsuka Pharmaceutical Co., Ltd., Tokushima Received for publication November 30, 1998; Accepted for publication May 29, 1999

Reprint requests should be addressed to Dr. Kei Sato, the Department of Internal Medicine, Anan Central Hospital, Kawahara Takarada-cho, Anan, Tokushima 774-0045 
Mutation in Vasopressin V2 Receptor Gene

Table 1. Laboratory Data

\begin{tabular}{lrlr}
\hline Urinalysis & & Hematology & \\
PH & 5 & Red blood cell & $179 \times 10^{4} / \mu \mathrm{l}$ \\
Protein & $(-)$ & Hemoglobin & $4.5 \mathrm{~g} / \mathrm{dl}$ \\
Sugar & $(-)$ & Hematocrit & $16 \%$ \\
Blood & $(-)$ & Platelet & $52.1 \times 10^{4} / \mu 1$ \\
Casts & $(-)$ & White blood cell & $5,570 / \mu \mathrm{l}$ \\
ESR & $35 \mathrm{~mm} / \mathrm{h}$ & & \\
Blood Chemistry & & & \\
GOT & $14 \mathrm{IU} / l$ & $\mathrm{Na}$ & $150 \mathrm{mEq} /$ \\
GPT & $13 \mathrm{IU} / l$ & $\mathrm{~K}$ & $4.0 \mathrm{mEq} / l$ \\
LDH & $347 \mathrm{IU} / l$ & $\mathrm{Cl}$ & $114 \mathrm{mEq} / l$ \\
$\gamma$-GTP & $11 \mathrm{IU} / l$ & $\mathrm{Ca}$ & $8.8 \mathrm{mg} / \mathrm{dl}$ \\
Total bilirubin & $0.3 \mathrm{mg} / \mathrm{dl}$ & $\mathrm{P}$ & $3.5 \mathrm{mg} / \mathrm{dl}$ \\
Total protein & $6.9 \mathrm{~g} / \mathrm{dl}$ & Fe & $25 \mu \mathrm{g} / \mathrm{dl}$ \\
Albumin & $3.3 \mathrm{~g} / \mathrm{dl}$ & $\mathrm{UIBC}$ & $452 \mu \mathrm{g} / \mathrm{dl}$ \\
BUN & $6.0 \mathrm{mg} / \mathrm{dl}$ & FBS & $109 \mathrm{mg} / \mathrm{dl}$ \\
Creatinine & $0.5 \mathrm{mg} / \mathrm{dl}$ & HbA & $4.1 \%$ \\
\hline
\end{tabular}

ESR: erythrocyte sedimentation rate, GOT: glutamic oxaloacetate transaminase, GPT: glutamic pyruvic transaminase, LDH: lactic dehydrogenase, $\gamma$-GTP: $\gamma$-glutamyl transpeptidase, BUN: blood urea nitrogen, UIBC: unsaturated iron binding capacity, FBS: fasting blood sugar, $\mathrm{HbA}_{1 \mathrm{C}}$ : glycohemoglobin $\mathrm{A}_{\mathrm{IC}}$.

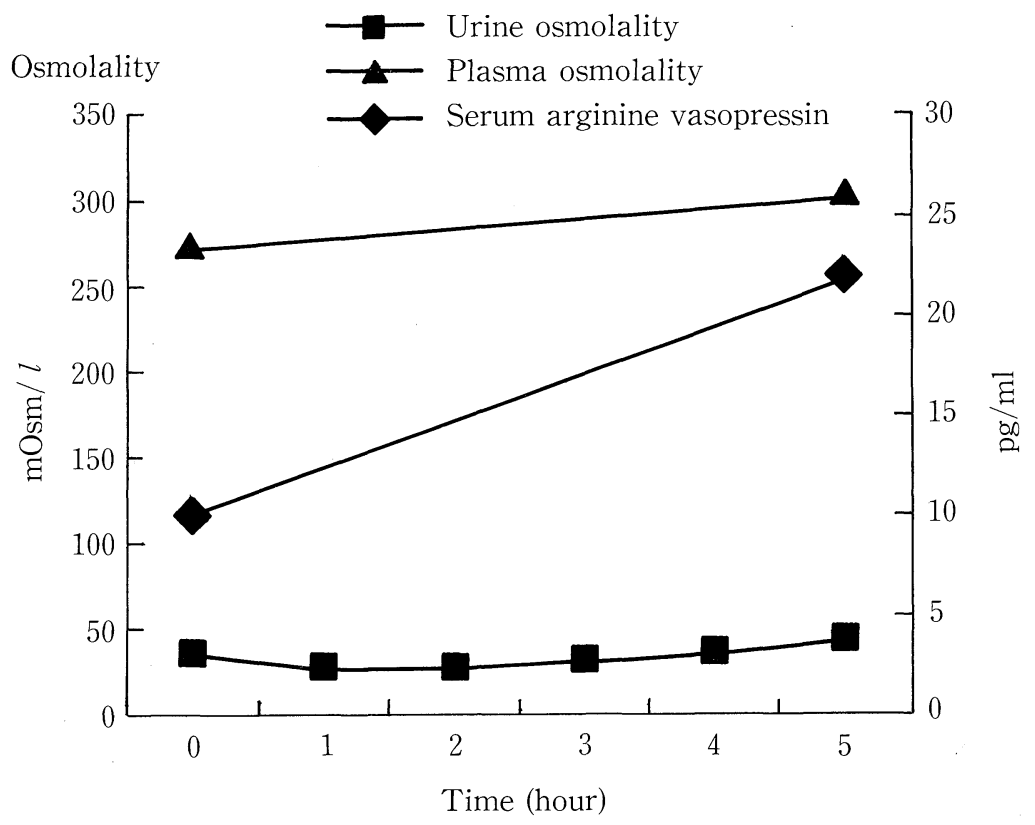

Figure 1. Water deprivation test. The patient failed to concentrate her urine despite increase in plasma osmolality.

$\mu \mathrm{g}$, however, urine volume was not decreased, so the daily dose of this agent was finally increased to $30 \mu \mathrm{g}$, still without reduction of daily urine volume. After one week, the plasma AVP level was as high as $10 \mathrm{pg} / \mathrm{ml}$ and increased to $22 \mathrm{pg} / \mathrm{ml}$ after a 5-hour water deprivation test.

She was diagnosed with CNDI on the basis of clinical manifestations including a lifelong history of polyuria and polydip- sia, elevated plasma concentrations of AVP, and unconcentrated urine despite water deprivation and exogenous administration of DDAVP. At 28th day after admission, total gastrectomy was performed. Unfortunately, the gastric cancer had disseminated throughout the peritoneum. Postoperatively, about $500 \mathrm{ml}$ fluid per hour was required to prevent dehydration, referring to an hour urine volume, central venous pressure, and plasma osmo- 

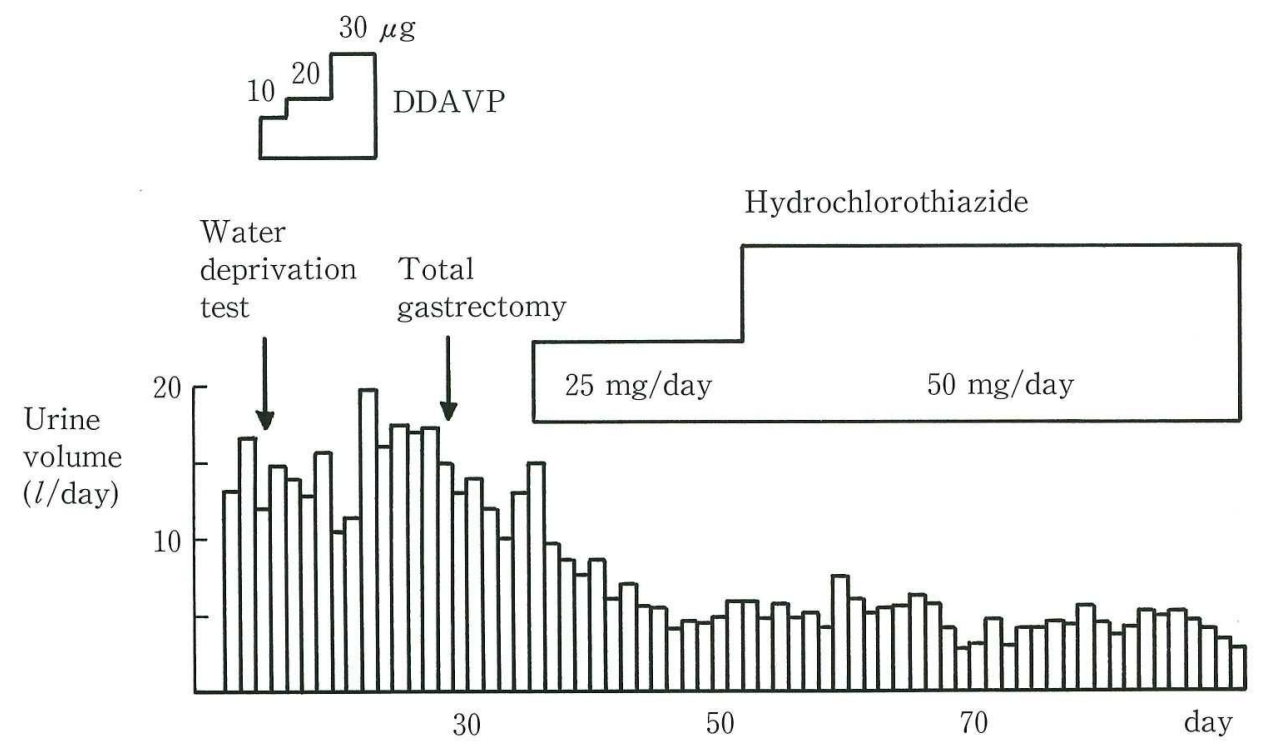

Figure 2. Clinical course of this patient. Daily urine volume was reduced by administration of hydrochlorothiazide.

lality. She was therefore treated with a low-solute concentrated diet and a thiazide diuretic (hydrochlorothiazide) (13). Serum electrolyte levels returned to normal and urine volume decreased to 3,000-4,000 ml/day (Fig. 2).

Direct dideoxy-DNA sequencing was performed for the entire coding region of the human vasopressin $\mathrm{V} 2$ receptor gene. Direct sequencing analysis revealed that the patient had a Gto-A transition at nucleotide position 631, altering codon 12 from $\mathrm{GGG}$ to $\mathrm{G} \underline{\mathrm{A} G}$ in the first extracellular domain (Figs. 3, 4).

\section{Discussion}

CNDI is a rare disease characterized by polydipsia and polyuria with low urine specific gravity from soon after birth. Unless recognized and treated early, persistent severe dehydration may lead to growth retardation and mental retardation, or death (14).

The present patient had consistently drank more than 10 liters of water per day because of thirst, therefore had no mental retardation and an average intelligence, and in addition had two healthy children. They exhibited no CNDI symptoms.

Since CNDI is generally transmitted as an X-linked recessive disorder, the clinical disorder occurs primarily in males (15). The patient's father died at age 31 of pulmonary tuberculosis, and exhibited no CNDI symptoms. Her mother also had no history of polyuria and polydipsia and did not have a mutation in the vasopressin V2 receptor gene. Thus, in this case the mutated gene was not inherited from her parents. She was heterozygous for this mutation, as a result of the random $\mathrm{X}$ chromosome inactivation $(16,17)$. She has a clinical form of CNDI. The human V2 receptor gene is located in the region of chromosome Xq 28 (18) and has three exons and two small introns

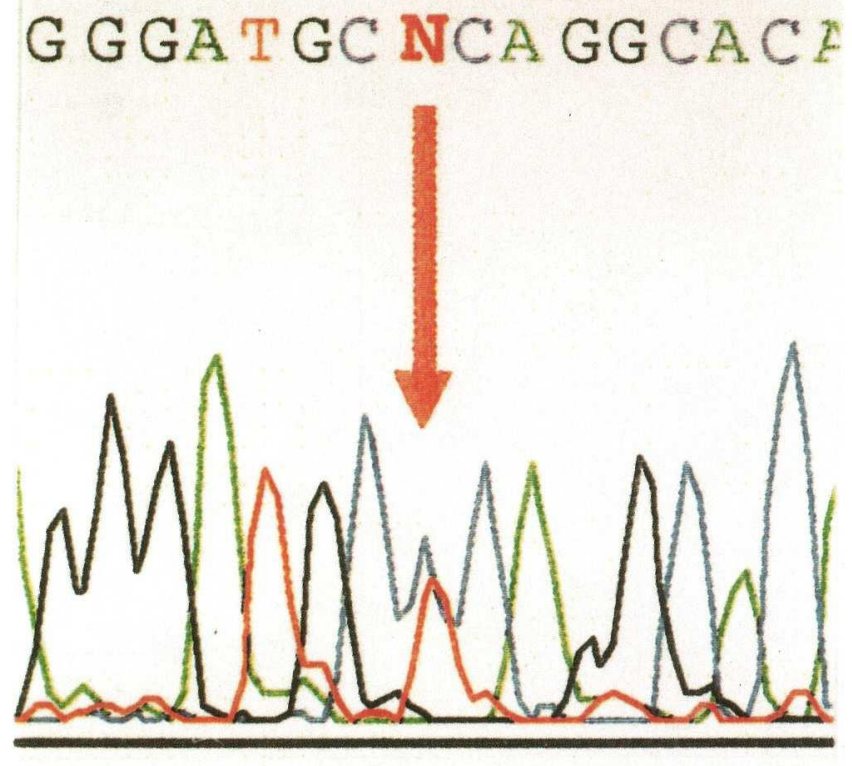

Figure 3. Direct sequencing of the fragment in coding region of arginine vasopressin $\mathrm{V} 2$ receptor gene. The fragments from the patient were studied with a dideoxy termination method. Underlined $\mathrm{N}$ indicates the substituted nucleotide.

(3). The cDNA sequence predicts a polypeptide of 371 amino acids with a structure typified by guanine nucleotide $(\mathrm{G})$, with seven transmembrane, four extracelluler and four cytoplasmic domains $(2,3)$. More than $70 \mathrm{~V} 2$ receptor gene mutations have been detected in CDNI families to date, including missense 


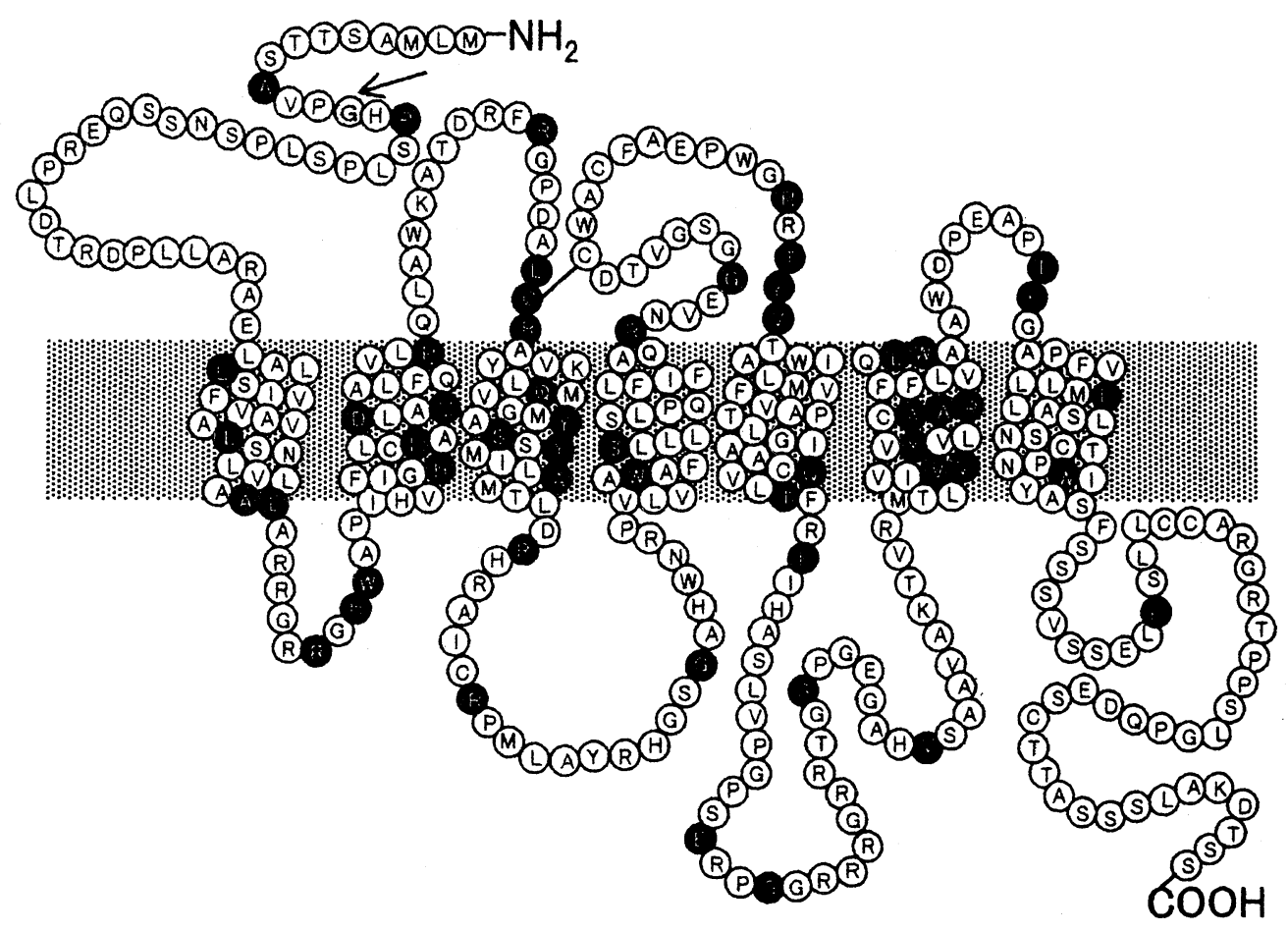

Figure 4. Structure of the vasopressin V2 receptor showing the extracellular, transmembrane and cytoplasmic domains. An arrowed $G$ residue indicate the missense mutation site from Gly to Glu.

mutations $(9,10,12)$, deletions $(4,6,8)$, insertions $(7,11)$, and nonsense mutations $(5,9,10)$ leading to a truncated receptor.

Holtzman et al reported a nonsense mutation at codon 231 resulting from a G-to-T transition (11). This mutation causes premature termination and truncation of the receptor protein, which then contains only 231 amino acids instead of the normal 371 . This protein potentially spans the cell membrane only five times instead of the usual, and lacks the entire carboxyl terminus of the receptor protein. Other nonsense mutations such as Q119X (5), L312X (12), and R337X (10) have also been reported. These nonsense mutations did not produce complete receptor proteins, and resulted in nonfunctional proteins. One type of deletion changes codon 246 from GGG to GGC, shifts the reading frame with an altered amino acid sequence beginning with codon 247 , and introduces a premature stop codon (TGA) at position 270 (4).

The resulting mutant receptor thus lacks the entire carboxylterminal third of the normal protein and retains only 17 of the amino acids of the third intracellular loop. The insertion of a single cytosine into the codon for leucine 228 in the V2 receptor sequence shifted the reading frame for protein translation (7). As a consequence of this change in the amino acid sequence, 40 percent of the receptor sequence at the carboxy terminus was disrupted, first by the generation of a missense amino acid sequence and then by premature termination.

The human V2 receptor has two cysteine residues (Cys 112 and Cys 192, in the second and third extracellular domains, respectively) which are conserved in the vasopressin receptor, suggesting that they are required for structural or functional integrity of the receptor (19). An arginine to cysteine missense mutation was found at codon 181 (5). It is thus possible that this Arg to Cys substitution disrupts the correct disulfide binding between extracellular loop I and II. In other cases, missense mutations such as Gly 185 to Cys, Tyr 205 to Cys, and Arg 203 to Cys have been reported (20). It is conceivable, then, that these extra cysteines interfere with the formation of disulfide bridges, which may affect vasopressin binding. Holtzman et al reported a missense mutation, arginine to tryptophan at codon 113 (21). They speculated that a change from a positively charged arginine residue to an amino acid with a large side chain with both hydrophobic and hydrophilic characteristics such as tryptophan, might interfere with the formation of disulfide bonds, thereby rendering the receptor dysfunctional because it remains trapped in intracellular organelles. The R137H mutant receptor exhibited unaltered binding affinity for vasopressin, compared to the wild type, but failed to stimulate the adenylate cyclase system (22).

In the present study, a direct sequencing analysis revealed her genomic DNA has a missense mutation from $\mathrm{G}$ to $\mathrm{A}$ at the 631 st nucleotide in an allele of vasopressin $\mathrm{V} 2$ receptor gene. The resulting 12th codon is substituted from glycine (GGG) to glutamic acid (GAG) by the missense mutation in the extracellular domain of vasopressin V2 receptor gene. The substitution leads to a change in the three-dimensional structure of the 


\section{SATo et al}

V2 receptor and decreases the binding affinity for vasopressin protein, since the polarity change of amino acid is lead by the substitution from the neutral amino acid to the acidic amino acid. This mutation was considered as the cause of CNDI in this case.

\section{References}

1) Skorecki KL, Brown D, Ercolani L, Ausiello DA. Molecular mechanisms of vasopressin action in the kidney. in: Handbook of Physiology. Section 8, Renal Physiology. Vol II. Oxford University Press, New York, 1992: 1185-1218.

2) Birnbaumer M, Seibold A, Gilbert S, et al. Molecular cloning of the receptor for human antidiuretic hormone. Nature 357: 333-335, 1992.

3) Seibold A, Brabet P, Rosenthal W, Birnbaumer M. Structure and chromosomal localization of the human antidiuretic hormone receptor gene. Am J Hum Genet 51: 1078-1083, 1992.

4) Rosenthal W, Seibold A, Antaramian A, et al. Molecular identification of the gene responsible for congenital nephrogenic diabetes insipidus. Nature 359: 233-235, 1992.

5) Pan Y, Metzenberg A, Das S, Jing B, Gitschier J. Mutations in the V2 vasopressin receptor gene are associated with $\mathrm{X}$-linked nephrogenic diabetes insipidus. Nat Genet 2: 103-106, 1992.

6) Tsukaguchi H, Matsubara H, Aritaki S, Kimura T, Abe S, Inada M. Two novel mutations in the vasopressin $\mathrm{V} 2$ receptor gene in unrelated Japanese kindreds with nephrogenic diabetes insipidus. Biochem Biophys Res Commun 197: 1000-1010, 1993.

7) Merendino JJ Jr, Spiegel AM, Crawford JD, O'Carroll AM, Brownstein MJ, Lolait SJ. Brief report: a mutation in the vasopressin V2-receptor gene in a kindred with $\mathrm{X}$-linked nephrogenic diabetes insipidus. $\mathrm{N}$ Engl J Med 328: 1538-1541, 1993.

8) Yuasa H, Ito M, Oiso Y, et al. Novel mutations in the V2 vasopressin receptor gene in two pedigrees with congenital nephrogenic diabetes insipidus. J Clin Endocrinol Metab 79: 361-365, 1994.

9) Bichet DG, Birnbaumer M, Lonergan M, et al. Nature and recurrence of AVPR2 mutations in X-linked nephrogenic diabetes insipidus. Am J Hum
Genet 55: 278-286, 1994.

10) Knoers NVAM, van den Ouweland AMW, Verdijk M, Monnens LAH, van Oost BA. Inheritance of mutations in the $\mathrm{V} 2$ receptor gene in thirteen families with nephrogenic diabetes insipidus. Kidney Int 46: 170-176, 1994.

11) Holtzman EJ, Kolakowski LF Jr, Geifman-Holtzman O, et al. Mutations in the vasopressin V2 receptor gene in two families with nephrogenic diabetes insipidus. J Am Soc Nephrol 5: 169-176, 1994.

12) Bichet DG. Vasopressin receptors in health and disease. Kidney Int 49: 1706-1711, 1996.

13) Lewis DJM, Thomas JP. Treatment of nephrogenic diabetes insipidus. $N$ Engl J Med 315: 1292-1293, 1986 (letter).

14) Bichet DG. Nephrogenic diabetes insipidus. in: Oxford Textbook of Clinical Nephrology, Cameron JS, Davison AM, Grunfeld JP, Kerr DNS, Ritz E, Eds. Oxford University Press, New York, 1992: 789-800.

15) Robinson MG, Kaplan SA. Inheritance of vasopressin-resistant ("nephrogenic") diabetes insipidus. Am J Dis Child 99: 164-174, 1960.

16) Lyon MF. Gene action in the $X$-chromosome of the mouse. Nature 190: 372-373, 1961.

17) van Lieburg AF, Verdijk MAJ, Schoute F, et al. Clinical phenotype of nephrogenic diabetes insipidus in females heterozygous for a vasopressin type 2 receptor mutation. Hum Genet 96: 70-78, 1995.

18) Kambouris M, Dlouhy SR, Trofatter JA, Conneally PM, Hodes ME. Localization of the gene for X-linked nephrogenic diabetes insipidus to $\mathrm{Xq}$ 28. Am J Med Genet 29: 239-246, 1988.

19) Lolait SJ, O'Carroll AM, McBride OW, Konig M, Morel A, Brownstein MJ. Cloning and characterization of a vasopressin V2 receptor and possible link to nephrogenic diabetes insipidus. Nature 357: 336-339, 1992.

20) van den Ouweland AMW, Dreesen JCFM, Verdijk M, et al. Mutations in the vasopressin type 2 receptor gene (AVPR2) associated with nephrogenic diabetes insipidus. Nat Genet 2: 99-102, 1992.

21) Holtzman EJ, Harris HW Jr, Kolakowski LF Jr, Guay-Woodford LM, Botelho B, Ausiello DA. Brief report: a molecular defect in the vasopressin V2-receptor gene causing nephrogenic diabetes insipidus. N Engl J Med 328: 1534-1537, 1993.

22) Rosenthal W, Antaramian A, Gilbert S, Birnbaumer M. Nephrogenic diabetes insipidus. A V2 vasopressin receptor unable to stimulate adenylyl cyclase. J Biol Chem 268: 13030-13033, 1993. 